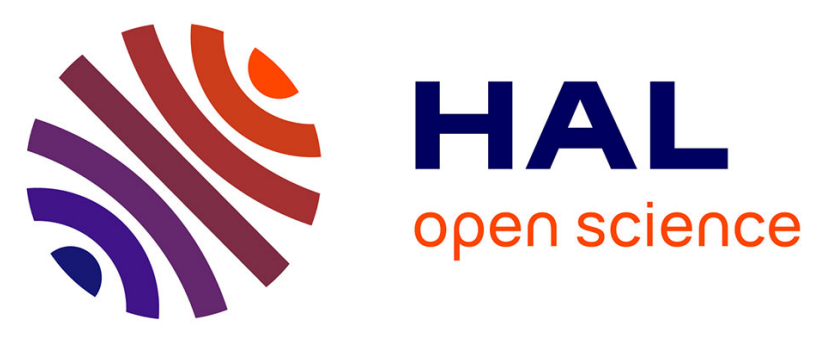

\title{
Territorial biodiversity and consequences on physico-chemical characteristics of pollen collected by honey bee colonies
}

\author{
Jean-François Odoux, Dalila Feuillet, Pierrick Aupinel, Yves Loublier, \\ Jean-Noël Tasei, Cristina Mateescu
}

\section{To cite this version:}

Jean-François Odoux, Dalila Feuillet, Pierrick Aupinel, Yves Loublier, Jean-Noël Tasei, et al.. Territorial biodiversity and consequences on physico-chemical characteristics of pollen collected by honey bee colonies. Apidologie, 2012, 43 (5), pp.561-575. 10.1007/s13592-012-0125-1 . hal-01003647

\section{HAL Id: hal-01003647 https://hal.science/hal-01003647}

Submitted on 1 Jan 2012

HAL is a multi-disciplinary open access archive for the deposit and dissemination of scientific research documents, whether they are published or not. The documents may come from teaching and research institutions in France or abroad, or from public or private research centers.
L'archive ouverte pluridisciplinaire HAL, est destinée au dépôt et à la diffusion de documents scientifiques de niveau recherche, publiés ou non, émanant des établissements d'enseignement et de recherche français ou étrangers, des laboratoires publics ou privés. 


\title{
Territorial biodiversity and consequences on physico-chemical characteristics of pollen collected by honey bee colonies
}

\author{
Jean-François Odoux ${ }^{1}$, Dalila FeuILlet ${ }^{2}$, Pierrick Aupinel ${ }^{1}$, Yves Loublier $^{1}$, \\ Jean-Noël TASEI ${ }^{1}$, Cristina MATEESCU ${ }^{3}$ \\ ${ }^{1}$ INRA, UE1255 Entomologie, Le Magneraud, BP52, 17700 Surgères, France \\ ${ }^{2}$ INRA, UE1206 EASM, Le Magneraud, BP52, 17700 Surgères, France \\ ${ }^{3}$ ICDA, Institutul Cercetare-Dezvoltare pentru Apicultura, Bucharest, Romania
}

Received 26 January 2011 - Revised 3 December 2011 - Accepted 23 January 2012

\begin{abstract}
Pollen resources may become a constraint for the honey bee in cereal farming agrosystems and thus influence honey bee colony development. This survey intended to increase knowledge on bee ecology in order to understand how farming systems can provide bee forage throughout the year. We conducted a 1-year study to investigate the flower range exploited in an agrarian environment in western France, the physicochemical composition of honey bee-collected pollen, the territorial biodiversity visited by the bee at different periods, and the relationships between these three datasets. Palynological analyses showed the importance of maize among crop pollens and that of weeds during the food shortage period. Pollen protein varied from $16 \%$ to $29 \%$ and lipids from $7 \%$ to $24 \%$. The contribution of different habitats to pollen harvest, was from crops $(62 \%)$, woods $(32 \%)$, grasslands $(4 \%)$, and gardens $(1 \%)$.
\end{abstract}

agrosystem / honeybee / floral biodiversity / pollen analysis / chemical analysis

\section{INTRODUCTION}

Since 1962, agrosystems have been considerably intensified due to the Common Agricultural Policy and farming systems represent the major land use (e.g., 46\% in France) (Agreste 2011). This intensification results in the standardization of land use (in particular, grasslands are replaced by cereals), in the mechanization of farming practices, and in the increasing use of inputs (fertilizers, pesticides, etc.) thus creating environmental problems (Benton et al. 2003). Agrarian landscapes are complex anthroposystems, consisting of a mosaic of different elements: natural

Corresponding author: J. Odoux, jean-francois.odoux@magneraud.inra.fr Manuscript editor: Peter Rosenkranz (forest massifs), semi-natural (forest fragments and hedgerows), and artificial (set aside lands, crops, and urban areas including gardens).

All agrosystems host a number of pollinator insects which play a crucial role in agriculture. One of the key species for pollination is the honey bee which has a very large foraging range and uses different landscape foraging habitats. Honey bees are spatial collectors and pollen their harvest could be considered as a "global" picture of the resources surrounding floral resources at any time of the year.

A large decline in honey bee populations is occurring today on a global scale (Cox-Foster et al. 2007; Glinski and Kostro 2007; Kievits 2007) which may affect a number of agricultural productions requiring insect pollination. Today the causes of this decline have not been completely identified (vanEngelsdorp et al. 
2009; Le Conte 2008), and the environmental aspects of this issue are cause for concern.

Authors have already described how a loss of floral diversity in cereal fields in modern cropping systems may have been overlooked until today (Olivereau 1996; Jauzein 2001). Fried et al. (2009) assessed the increasing evidence of biodiversity loss during the last 40 years in North-East France agricultural landscapes, where $40 \%$ of weed species had significantly declined while $10 \%$ had significantly increased, in particular nitrophilous species. In such cropping where intensive chemical weeding is currently used, pollen resources may become a constraint for honey bees, and result in weak colony development and poor survival, due to loss of immunocompetence (Alaux 2010). Resource sustainability has to be taken into account throughout the year to ensure both the development of the bee colony and its overwintering capacity. In addition, the complementary nutritional aspects of multifloral pollen provisions are the guarantee of a balanced quality food able to produce healthy honey bees. During food shortage periods alternative flower resources, such as attractive wildflower strips, can play a survival role for bee colonies (Decourtye et al. 2010).

Pollen quality has been studied for a long time, in particular for its nutritional content (Haydak 1970; Campana and Moeller 1977; Standifer et al. 1980). Authors showed that physico-chemical characteristics of pollen harvests varied during the flight period since the average pollen spectrum varies during the year. Manning (2001) reviewed how pollen chemical composition influenced bee health and in particular he investigated the effects of lipid-enhanced food on bees. Obviously, in a modern crop system no global study has investigated both how honey bees exploit the various plant habitats and how floral elements of the landscape provide quality pollen amounts to colonies

We defined three objectives to investigate over one whole year the relationships between: (1) pollen harvested by colonies and landscape habitats, (2) the diversity of pollen harvested and their physico-chemical content, and (3) the contribution of different landscape habitats to physico-chemical content of pollen.

We quantified pollen resources available to bees within their flight range during a year and the flower range exploited in an intensive farming system environment. The study concerned three categories of data analyses of (1) the landscape habitat composition, (2) the honeybee-collected pollen, and (3) the physico-chemical composition of the pollen harvest.

\section{MATERIALS AND METHODS}

This survey was carried out in 2006 using honey bees from the apiary of our experimental centre in an agrarian environment in western France. We considered the different categories of flowers known to supply food resources to bees. Attractive crops are characterized by varieties, sowing date, irrigation, and pesticide use, weeds which depend on farming practices (ploughing, hoeing, fertilization, herbicides, etc.), trees and shrubs, especially forest borders and hedgerows, grasslands, gardens, and also anthropic structures (road banks, industrial areas, etc.).

\subsection{Land use monitoring}

The different land uses were recorded within a 2,500$\mathrm{m}$ radius around the hives, which was further than the mean foraging distance of $1,743 \pm 95 \mathrm{~m}$ observed by Steffan-Dewenter and Kuhn (2003). The proportions of landscape elements were computed using GIS Software (ArcGIS, version 9.3.1). Woods covered $26 \%$ of the area; sunflower, $26 \%$; cereals (wheat and barley), $20 \%$; grassland, $11 \%$ (including legumes); gardens and orchards, $5 \%$; rapeseed, $5 \%$; maize, $4 \%$; proteageneous peas, $2 \%$; set-aside fields, $1 \%$; and sorghum, $<1 \%$. Four classes of environment were found: (1) woods and semi-natural elements of landscape, (2) crops (cereals, maize and sorghum, peas, sunflower, rapeseed, etc.), (3) grassland, and (4) gardens. These classes covered 26\%, $58 \%, 11 \%$, and $5 \%$, respectively (Figure 1). However, the foraging activity area varied throughout the year because of the cropping system cycle. In order to assess the effective surface for bee foraging, we considered the field area as described in section 2.4. 
Figure 1. Experimental area and land use. The apiary is in the middle of the area (46 $09^{\circ} 13^{\prime \prime} \mathrm{N}$; $\left.0^{\circ} 41^{\prime} 20^{\prime \prime} \mathrm{O}\right)$.

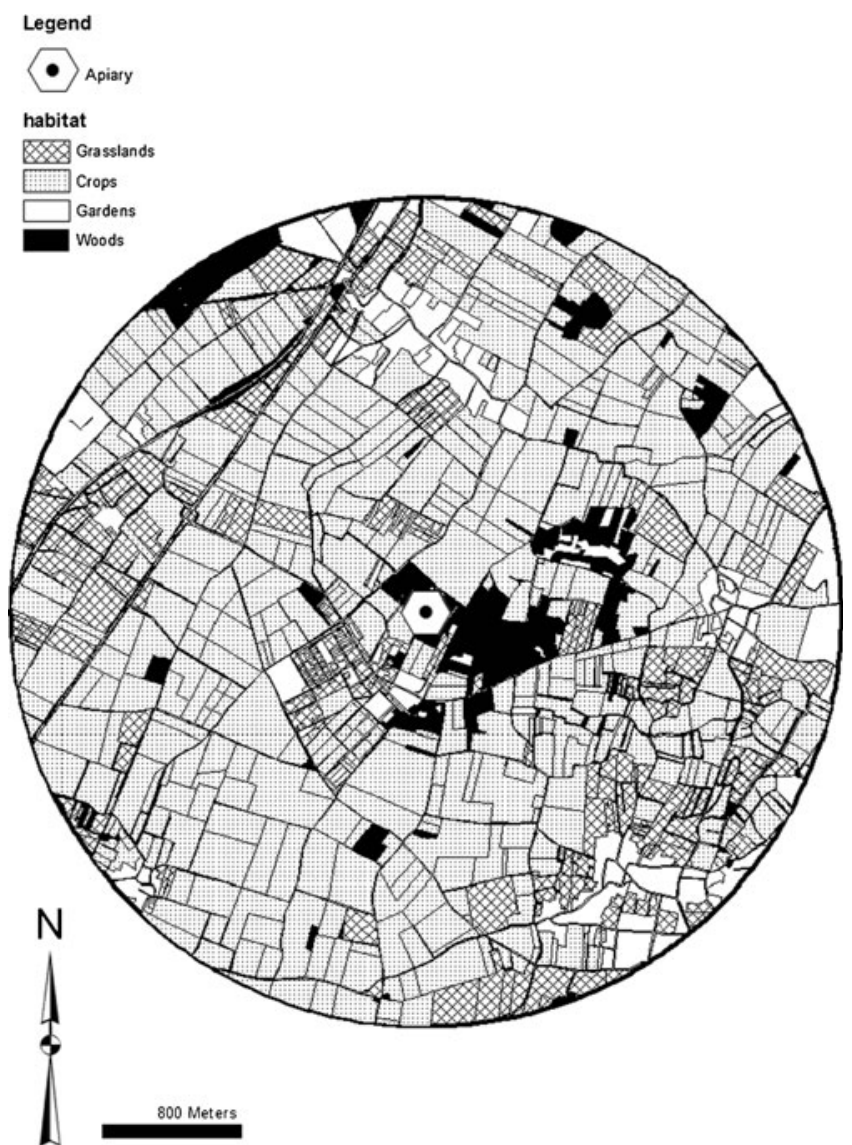

\subsection{Pollen sampling and palynology}

In order to focus only on the seasonal variation of pollen collection, we set up pollen traps on ten colonies of equal strength, randomly chosen within an apiary of 60 hives. We sampled pollen throughout the whole year except during ten winter weeks. We considered a unique mixed sample representing the pollen collected weekly. The colonies (Apis mellifera L.) were equipped with bottom pollen traps continuously in service. Their hole size was $5.3-\mathrm{mm}$ diameter and represented a common model of pollen trap, though considered less efficient than $4.8 \mathrm{~mm}$ (Bienkowska and Pohorecka 1996). According to Louveaux (1958) and Lavie and Fresnaye (1963), when using metal grid with 5-mm holes the trapping rate is assessed at $10 \%$ of the total pollen harvest (temporary variations $\pm 5 \%$ ). After each harvest, impurities were removed with forceps and mixed samples were weighed (Sartorius, $d=0.01 \mathrm{~g}$ ). Each pollen mix collected from the ten hives was coarsely homogenised in a large tin. Then, from four different places of this tin, we sampled $4 \times 6.25-\mathrm{mL}$ pollen. These $25-\mathrm{mL}$ samples were labelled, frozen at $-18^{\circ} \mathrm{C}$, and kept until the palynological and physico-chemical analyses were performed.

The pollen samples were poured into a dish from which four $1 \mathrm{~g}$ pre-samples were taken and mixed together. These mixed pellets were diluted in water, homogenized and kept $1 \mathrm{~h}$ at room temperature in an Erlenmeyer vessel. The suspension was stirred for $5 \mathrm{~min}$ with a magnetic stirrer, and two microscopic slides were prepared, each with one drop of the suspension. The microscopic preparations were dried and cleaned with alcohol and then covered with a drop of glycerine gelatine mixture stained with fuchsine, according to the technique described by Louveaux et al. (1978). 
At least 1,000 pollen grains were observed per slide. An Olympus B-52 microscope $\times 400$ with a camera connected to a computer was used to identify and count pollen grains of the different taxa (Software 2I system-Paris Pégase Pro V4). The end point of this study was the assessment of the volume of each pollen species more representative than classical grain numbering. Brian (1957) argued for considering the relative importance of the volume of pollen grain in a food study, and showed high differences between the proportions by number and by volume. Floral species ratios within a sample were estimated by considering the pollen grain as a sphere with a specific diameter. A preliminary assay conducted on pure pellets of four floral species $(n=19$ pollen samples) focussed on the relationship between the weight of a pellet, the pollen grain volume, and the number of pollen grains in the pellet. It was concluded that pollen grain weight was correlated to grain volume (Spearman coefficient, $P<0.001$ ). The weighed amount of each pollen species collected each week was computed by multiplying the percentage by volume of each floral species assessed in the microscopic slides and the weight of pollen harvest. Specific amounts are expressed in grams per day per hive in section 3 .

The palynological method did not always allow the discrimination of very close taxa. In such cases, a reference genus was assigned to several pollen types, e.g., Brassica reference covered cabbage, Raphanus, some oil seed rape varieties, and other various wild crucifers.

According to our local botanical database available by internet at http://www.guenievre.magneraud. inra.fr/entomologie, each taxon was assigned to one of the four habitats. When a species is present in several habitats, it is assigned to the habitat where it is more abundant.

\subsection{Physico-chemical characterization of pollens}

For the physico-chemical characterization, the pollen samples were ground with a household mixer. The dry matter content was determined after heating at $75^{\circ} \mathrm{C}$ during $24 \mathrm{~h}$ (Louveaux 1959). The protein content was determined by Kjeldahl method $(N \times$ 6.25) according to ISO 5983 norm, using a Vapodest
45 Gerhardt automat. Reducing sugar determination was carried out after deproteinization with the colorimetric method (Elser and Ganzmüller 1931).

For the total lipid determination, Folch et al. (1957) method was applied. In order to extract also the internal lipids contained in the pollen grain (Roulston and Cane 2000), a disruption of the pollen wall (exin) was necessary, using hydrochloric acid ( $\mathrm{HCl} 6 \mathrm{~N}$ ) hydrolysis. Following the acid hydrolysis, an extraction with a chloroform/ methanol mixture $(2: 1, v / v)$ was carried out for each pollen sample.

The physico-chemical analyses results are expressed in percent of the dry matter.

\subsection{Diversity and resources indexes}

Diversity was always calculated on the habitat criterion, for landscape and pollen as well. The Shannon diversity index $\left(H^{\prime}\right)$ presented was calculated as $H^{\prime}=-\Sigma \mathrm{p} i \cdot \log _{2} \mathrm{p} i$ where $\mathrm{p} i$ was the habitats relative area for landscape diversity, or pollen abundance from each habitat for pollen diversity (Shannon and Weaver 1949). It allowed the assessment of the diversity gradient for habitat area or pollen samples.

Based on pollen analyses, the available pollen resources index has been expressed each week for the four habitats. This index is the sum of the theoretical frequencies of every taxa calculated using the area (in ha $\cdot 10^{3}$ ), multiplied by a coefficient taking into account a theoretical frequency of each taxon in the landscape. The blooming periods were established using our botanical database (www.poitou-charentes. inra.fr/entomologie). A special calculation has been performed for the crops: rapeseed, winter cereals, sunflower, and maize where weeds were taken into account. The frequency of each weed species was provided by ARAF and HYPPA weed databases from UMR1210 "Biologie et Gestion des Adventices" INRA Dijon (www2.dijon.inra.fr/bga/hyppa and www2.dijon.inra.fr/bga/araf2009) which takes into account the preceding crops.

\subsection{Statistics}

The statistical analyses were checked by the $R$ software (the R Foundation for Statistical Computing, 
version 2.11.1) and the Access software (Microsoft Corporation).

All variables were analyzed using generalized linear models, concerning landscape, physicochemical components, and flora foraged during each week.

A multivariate analysis was performed from weekly samples by hierarchical cluster analysis (HCA-Ward) of $H^{\prime}$ identifying different classes characterized by their diversity level. Homogeneous chronological periods were determined, based on these classes and taking into account the highlighting of some identified species as well. Based on the $H^{\prime}$, principal component analysis (PCA) was performed on habitat data during the main periods from weeks 16 to 32 .

\section{RESULTS}

\subsection{Diversity of landscape and harvest}

Figure $2 \mathrm{a}$ shows that maximum resources, including the weed blossom mass present in each crop, were observed between weeks 22 and 39, namely in summer (coefficient, $>5$ ). According to the pollen diversity illustrated in Figure 2b, five clusters can be distinguished: cluster I, weeks 1$15\left(H^{\prime}=2.00\right)$; cluster II, weeks $16-21$ and 24-27 $\left(H^{\prime}=1.92\right)$; cluster III, weeks 22,23 , and $30\left(H^{\prime}=\right.$ 1.84); cluster IV, weeks 28-29 and 31-32 ( $H^{\prime}=$ $1.83)$; and cluster V, weeks 33-52 $\left(H^{\prime}=1.38\right)$. The cluster includes all taxa collected identified by palynological analyses. In total, 92 floral species were found throughout the year corresponding to $22 \%$ of the species recorded in our local melliferous plants database. In order to assess in detail the species contribution, the total estimated weights of the major flowers within each complete cluster are given in Table I. The amounts of each taxon in grams have been computed per habitat. Crops and woods were the major pollen suppliers throughout the year, accounting for $92 \%$ of the total harvest, $61.25 \%$ and $31.36 \%$, respectively. The contribution of grasslands and gardens were only $4.5 \%$ and $1 \%$, respectively. The main species for crops habitat were Zea mays, Papaver, Sinapis, and Sorghum whereas for woods habitat were Rosaceae, Hedera, Cornus, and Acer. The contribution of Papaver, Z. mays, and Sorghum took place between weeks 22 and 32, and that of Rosaceae, Cornus and Acer between weeks 16 and 27. Between weeks 33 and 52, Sinapis and Hedera were the major pollen suppliers.

\subsection{Habitat origin of taxa collected}

The total weight of pollen collected in the traps during 1 year was 4,817 g/colony. Considering the four habitats defined above, the portion of pollens from the cropped area, woods, grasslands, and gardens was $62.0 \%, 32.2 \%, 4.5 \%$, and $1.3 \%$ of the total harvest, respectively. Within the cropped area, crops accounted for $27.2 \%$ and weeds for $34.8 \%$. Within the whole year, pollens from the cropped area (crops plus weeds) represented $3,003 \mathrm{~g} /$ colony ( $60 \%$ in clusters III and IV), the gardens $55 \mathrm{~g}$ (57\% in cluster II), the grasslands $221 \mathrm{~g}(65 \%$ in clusters II and III), and the woods $1,537 \mathrm{~g}$ ( $75 \%$ in clusters II and III). However, Figure 3 shows the important contribution of wood pollen from weeks 11 to 27 and 36 to 45 . The spring collection contained high amounts of Rosaceae type Prunus avium (up to $79 \%$ and $22 \mathrm{~g} /$ day), Cornus (up to $46 \%$ and $21 \mathrm{~g} /$ day), Acer (up to $50 \%$ and $11 \mathrm{~g}$ /day), Sambucus (up to $7 \%$ and $3 \mathrm{~g} /$ day), Quercus (up to $15 \%$ and $3 \mathrm{~g}$ /day), and Fraxinus (up to $31 \%$ and 2 g/day). The autumn period was mainly characterised by the crucial contribution of Hedera (up to $77 \%$ and $13 \mathrm{~g} /$ day). The cropped areas were mainly foraged in summer, for Zea (up to $77 \%$ and $36 \mathrm{~g} /$ day), Sorghum (up to $37 \%$ and $18 \mathrm{~g} /$ day), and Helianthus (up to $70 \%$ and $9 \mathrm{~g}$ /day). Brassica napus never represented more than $29 \%$. Weeds were foraged for Papaver (up to 66\% and $36 \mathrm{~g} /$ day), Sinapis (up to $98 \%$ and $17 \mathrm{~g} /$ day), Daucus/Ammi, Cichorium (up to $27 \%$ and $48 \%$, respectively, and $5 \mathrm{~g} /$ day), Hypericum, Plantago, (up to $15 \%$ and $13 \%$, respectively, and $2 \mathrm{~g} /$ day), Mercurialis (up to $55 \%$ and $1 \mathrm{~g}$ /day), Reseda, Caryophyllaceae, Polygonum, Persicaria, Chenopodium/Amaranthus ( $\max 1 \mathrm{~g} /$ day). These taxa represented a large part of the pollen harvested in summer, whereas Veronica (up to 
(a)

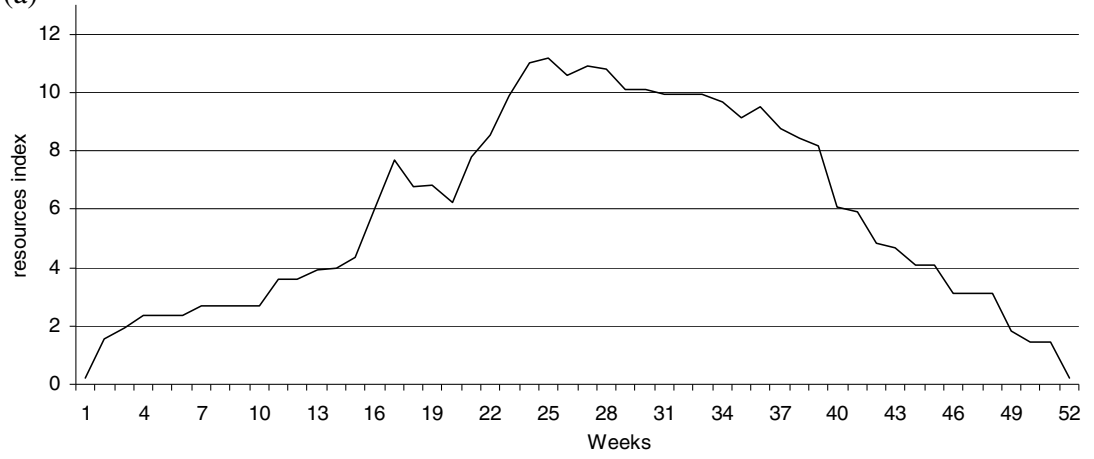

(b)

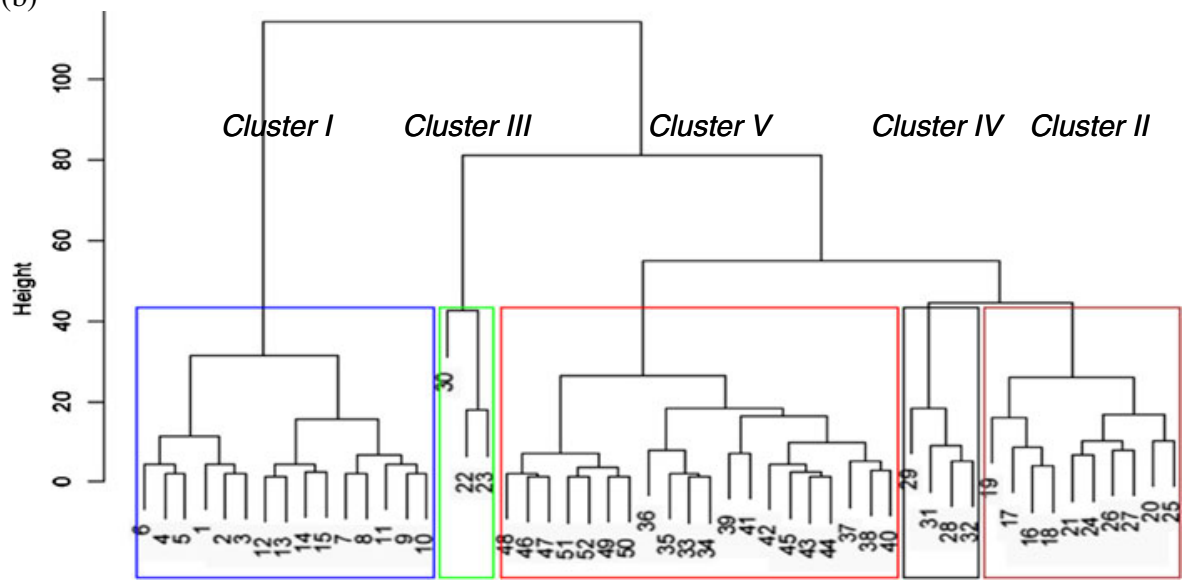

Figure 2. Available pollen resources in the landscape, and diversity of harvests by honeybees. a Pollen index throughout the year. b Clustered weeks according to Shannon diversity index $\left(H^{\prime}\right)$ of the pollen harvest.

$89 \%$ and $2 \mathrm{~g} /$ day), was the main pollen resource at the end of winter. A significant contribution of grasslands occurred in spring, with Onobrychis (up to $8 \%$ and $4 \mathrm{~g} /$ day), Vicia (up to $32 \%$ and $4 \mathrm{~g}$ /day), Taraxacum (up to $45 \%$ and $3 \mathrm{~g}$ /day), Trifolium ( $\max 2 \%$ and $1 \mathrm{~g} /$ day), and later Medicago (up to $25 \%$ and $3 \mathrm{~g}$ /day). The garden flowers (Elaeagnus, Viburnum, Platanus, Berberis, Aesculus, etc.) were visited throughout the year but in small amounts (max $1 \mathrm{~g}$ /day) which are not visible in Figure 3.

\subsection{Physico-chemical content}

The sugar content of pollen pellets varied from $14.6 \%$ to $41.1 \%$. High values occurred in summer during weeks $22-28(31.2 \%$ to $41.0 \%)$ and weeks 33-36 (27.4\% to $33.6 \%$ ) (Figure $4 a)$. On the contrary, low values $(<25 \%)$ appeared after week 37 during autumn. The pollen trapped per day and per hive, brought the highest amounts of sugar to colonies during weeks $22-23$, i.e., 26.1 and 23.2 g, respectively, $34.4 \%$ and $41.0 \%$ sugar (Figure $4 b$ ). Another period with high sugar provisioning was weeks 28 to 30 (9.8 to $15.7 \mathrm{~g}$ and $24.4 \%$ to $31.2 \%$ ). The sugar-low pollen was observed in autumn, after week 40, and brought less than $3.8 \mathrm{~g}(14.6 \%$ to $25.6 \%)$. The taxa concerned by high-sugar pollens were Papaver and Rubus in spring, and Cichorium and Sinapis in summer (Table I).

The protein content varied from $16.7 \%$ to $29.9 \%$ (annual average, 24.5\%). The highest level 


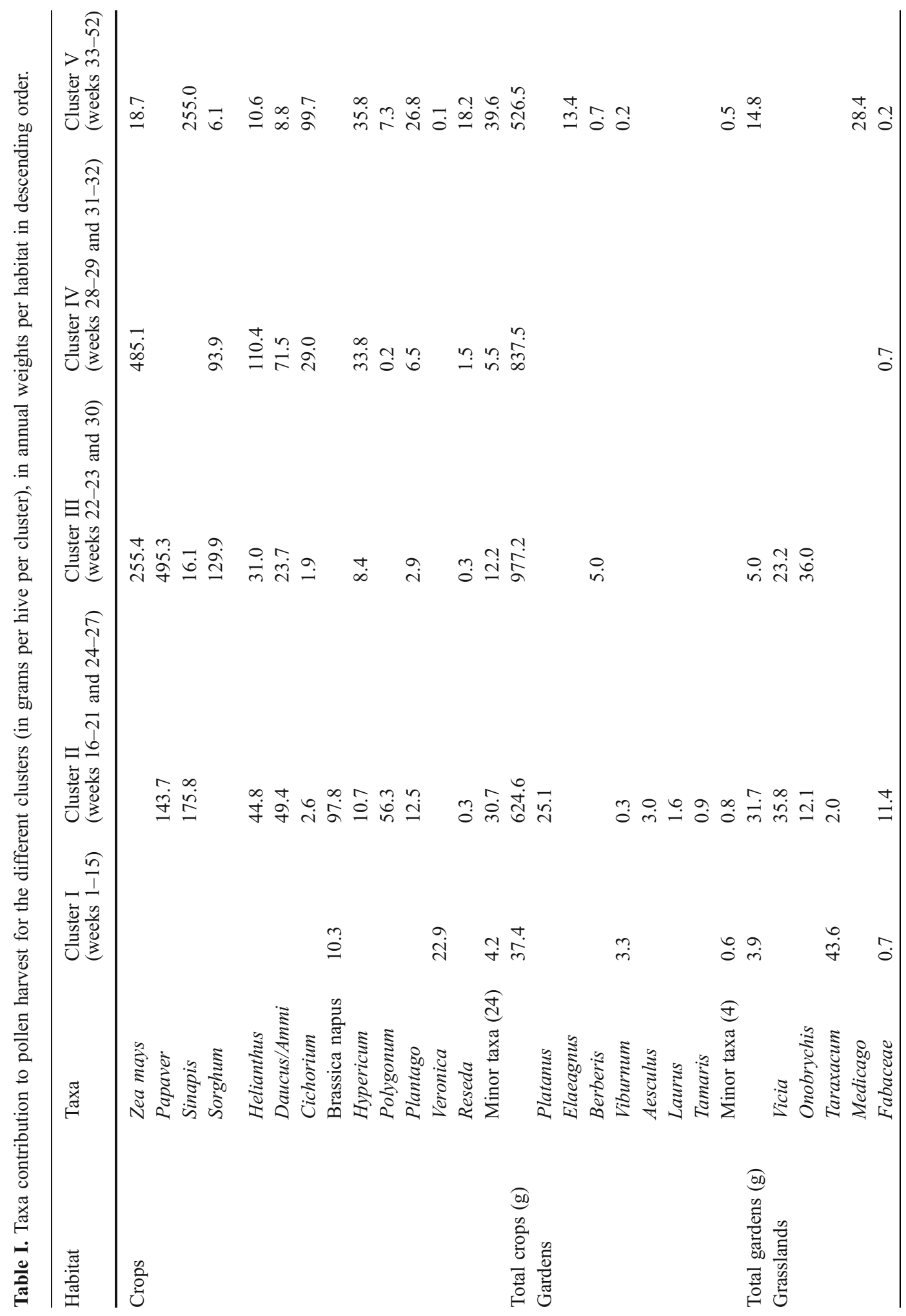




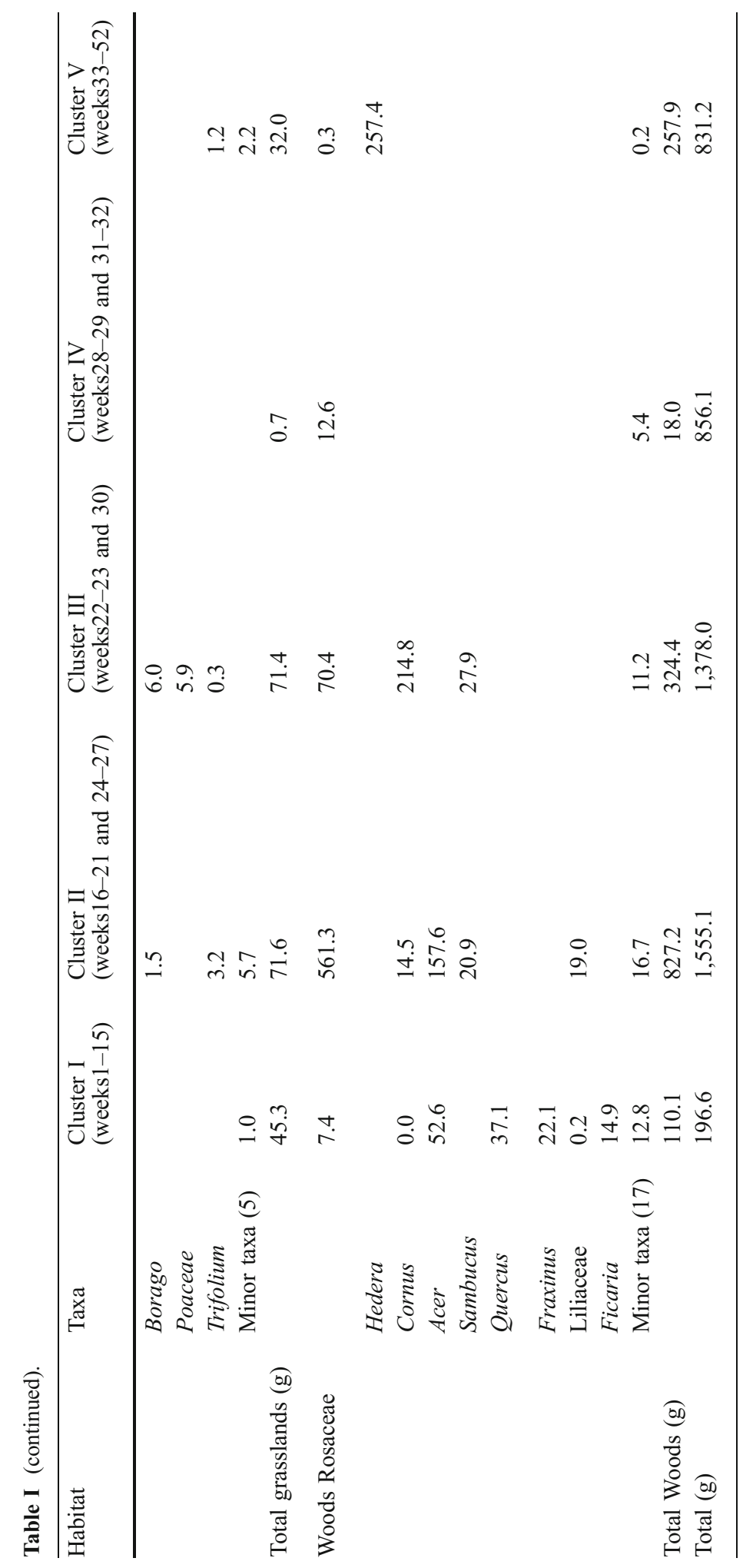

\section{Springer SDIB INRA}


Figure 3. Habitat contribution to pollen collection (weekly mean per colony).

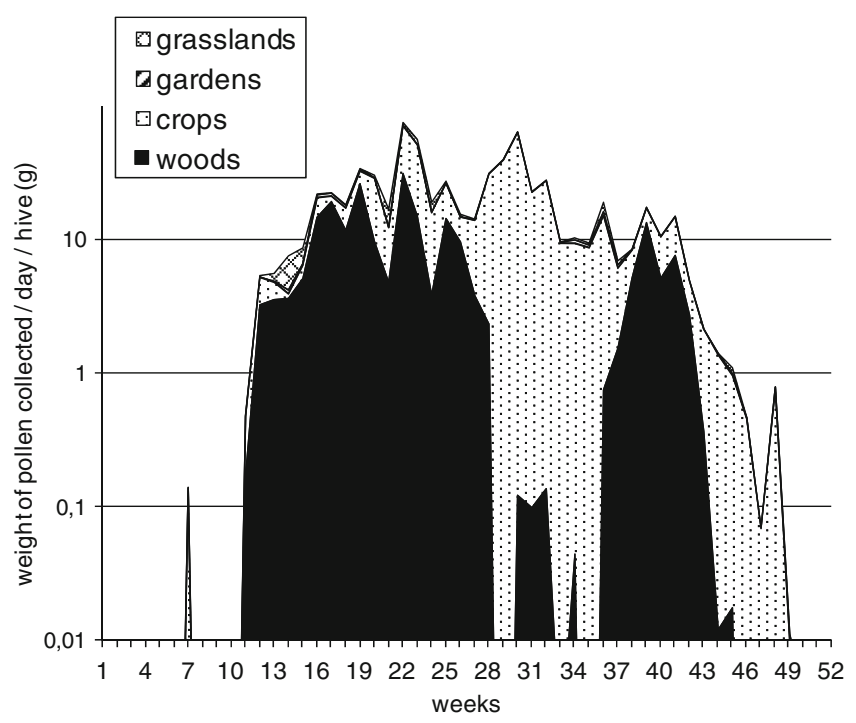

of protein was in spring, weeks $16-19$ (28.6\% to $29.1 \%$ ), and in autumn after week $44(26.0 \%$ to $29.9 \%$ ). Lower values occurred early in spring, up to week 14 (20.0\% to $24.5 \%)$, and in summer, from weeks 24 to 36 (16.8\% to $24.0 \%$ ) (Figure $4 a)$. The protein amounts were the highest during weeks 16-23 in spring, and then during weeks 2830 in mid-July (Figure 4b). The quantities provided per day and per hive ranged from 4.7 to $19.6 \mathrm{~g}$ and 5.8 to $11.3 \mathrm{~g}$, respectively, whereas the pollen protein percentage varied from $25.8 \%$ to $29.1 \%$ in spring and from $16.7 \%$ to $18.3 \%$ in summer. The protein diet decreased impressively after week 41, in mid-October. The annual average was $4.4 \mathrm{~g} /$ week. The most important protein provider habitats were crops and woods, especially in spring (Figure 3), with a high contribution of Papaver/Cornus, (14.8 to $19.6 \mathrm{~g}$ and $25.8 \%$ to $26.2 \%$ protein) and also in summer with large amounts of crop pollens Zea/Sorghum (5.8 to $11.3 \mathrm{~g}$ and $16.7 \%$ to $18.4 \%$ protein) (Table I). Selected pure Z. mays pollen loads were analyzed and contained $15.7 \%$ of protein.

Lipids varied greatly with a 3.25 ratio between the lowest level in week $29(7.5 \%)$ and the highest level in week 44 (24.4\%) (Figure $4 a)$. The annual mean lipid content was $12.6 \%$. The maximum lipid amount of pollen per day and per hive was provided during weeks 22-23 (June) with 7.2 and $5.3 \mathrm{~g}$ (around 9.5\% lipids) (Figure 4b). Weeks 24 to 27 (mid-June to mid-July) were characterized by a strong decrease in lipid amounts with 1.4 to $3.2 \mathrm{~g}(8.8 \%$ to $11.6 \%$ lipids). Until week 41 (October), lipid amounts reached up to $4 \mathrm{~g}$, and pollen contained $11.7 \%$ to $24.4 \%$ lipids, and then dropped. As for proteins, crop elements were the most important habitat contributing to lipid supply (Figure 3). Papaver was predominant in weeks 22-23 (5.4 to $7.3 \mathrm{~g}$ and 9.4-9.5\% lipids) and Zea/Sorghum in weeks 28-30 (3 g and $7.5 \%$ to $9.7 \%$ lipids) (Table I). Sunflower peak pollen represented up to $1.4 \mathrm{~g}$ and $9.6 \%$ lipids (week 27), and rapeseed 1.3 to $3 \mathrm{~g}$ and $11.2 \%$ to $16.6 \%$ lipids (weeks $15-18$ ). The annual lipid supply was $2.0 \mathrm{~g} /$ week.

\subsection{Relationships between the landscape and the harvested pollen (floral and chemical parameters)}

Concerning the relationship between the foraged habitats and the physico-chemical composition of the diet, woods, crops, and grassland pollens influenced sugar and protein amounts $(P<$ 0.001). Lipid supplies were also explained by pollen collected from woods and crops $(P<$ $0.001)$, and grasslands and gardens as well $(P<$ $0.05)$. Obviously, the pollen diversity expressed by $H^{\prime}$ does not explain either sugar, protein, or lipid supplies. 
Figure 4. Physico-chemical composition of pollen harvested throughout the year a in percentage of samples and b in weekly diet of bee colony.

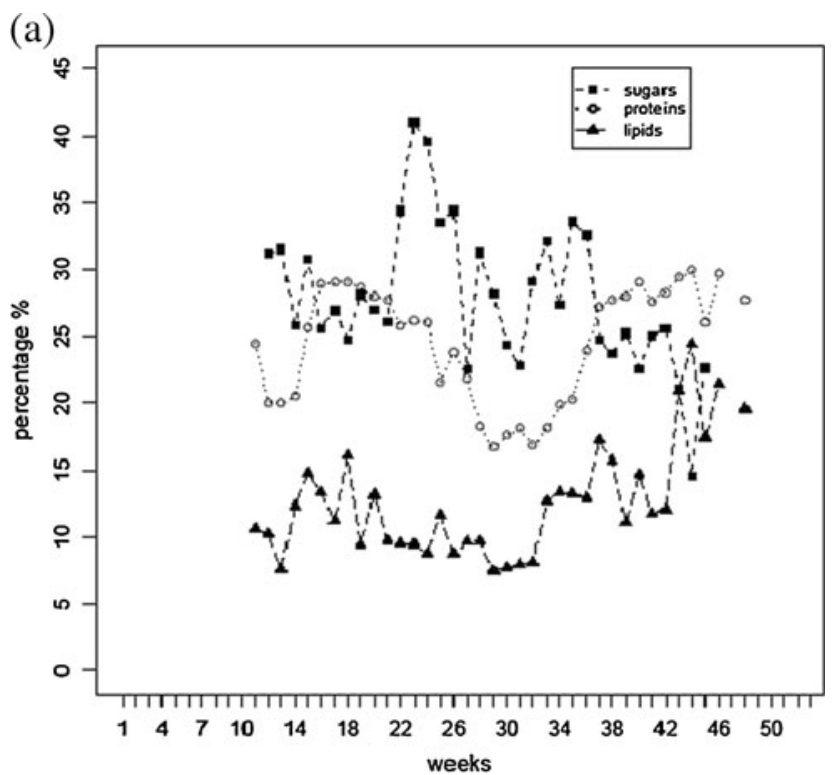

(b)

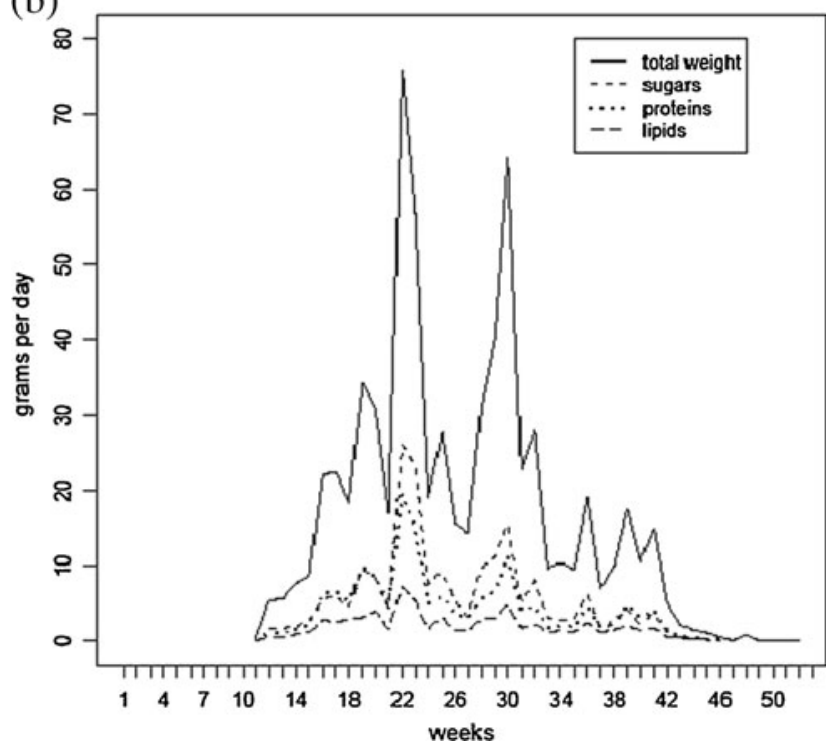

We observed a negative relationship between the land use diversity and the resources $(P<$ $0.001)$. The land use diversity is positively linked with the woods and gardens resources and negatively with the crops one as well $(P<$ 0.05). Concerning the relationship between the land use and the foraged habitats, the contribution of woods was correlated to their resources $(P<0.001)$. However, the pollen diversity was linked to the amounts of pollen harvested from woods $(P<0.001)$, gardens and grasslands $(P<$ $0.05)$. The more the resources increased, the more the pollen diversity increased $(P<0.001)$. Considering $H^{\prime}$, the land-use diversity and the pollen diversity were positively correlated $(P<$ $0.05)$, and in particular during spring (Figure 5).

Concerning land use and physico-chemical composition of the diet no relationship could be established between habitat areas and any component. In addition, resources index influenced protein 
and lipid supply. Nevertheless, the land use diversity was not correlated with any component.

\section{DISCUSSION}

The aim of this work was not to test the factors of pollen foraging by bee colonies, but to consider the landscape elements supplying pollen. In this regard, we did not perform individual measurements on colony parameters neither their pollen collection but mixed the pollen harvests of ten colonies which were intended to reflect the available resources of a cropped environment. Authors generally carried out studies on physicochemical characterization or nutritive value of single species bee-pollen (Maurizio 1950; Evans et al. 1987; Somerville 2001; Genissel et al. 2002) but did not take into account the mix managed by the bee colony exploiting a given landscape. Our study focused on the choice of pollens by bees in an agrarian environment where the flora was linked with agricultural practices, and within succeeding periods throughout the year. We suggest that the cropping landscape can influence the choice of the bee gatherers and that the interaction of different habitats is an insurance to compensate for shortage periods.

Figure 5. PCA of landscape diversity and pollen diversity harvest in clusters II to IV. The two central arrows tend towards the same side, close to the spring weeks.
Based on Winston's yearly evaluation of 15$55 \mathrm{~kg}$ pollen/hive (Winston 1994), we conclude that our average collection of 4,817 g means that our trap efficiency was $9 \%$ to $33 \%$ of the harvest and can be considered as correct in regard to authors' results (Louveaux 1958; Bienkowska and Pohorecka 1996). Using Lavie and Fresnaye's (1963) pollen trapping efficiency of $10 \%$, each of our colonies collected an average $48 \mathrm{~kg}$ pollen/ year.

\subsection{Relationship between the pollen harvest and the landscape}

The environment of our study was typical of a cereal plain with fragmented woods and very few grasslands. Oil-seed plants (sunflower and rapeseed) covered a large part of the farming area $(30.9 \%)$. Negative relationship between landscape diversity and the habitats area can be explained for crops which are by far the major land use in front of few large classes which made up index diversity calculation. The latter did not allow us to show positive correlations between pollen quantities harvested and the landscape. The pollen diversity explained by the foraging resources index revealed more adequate method of

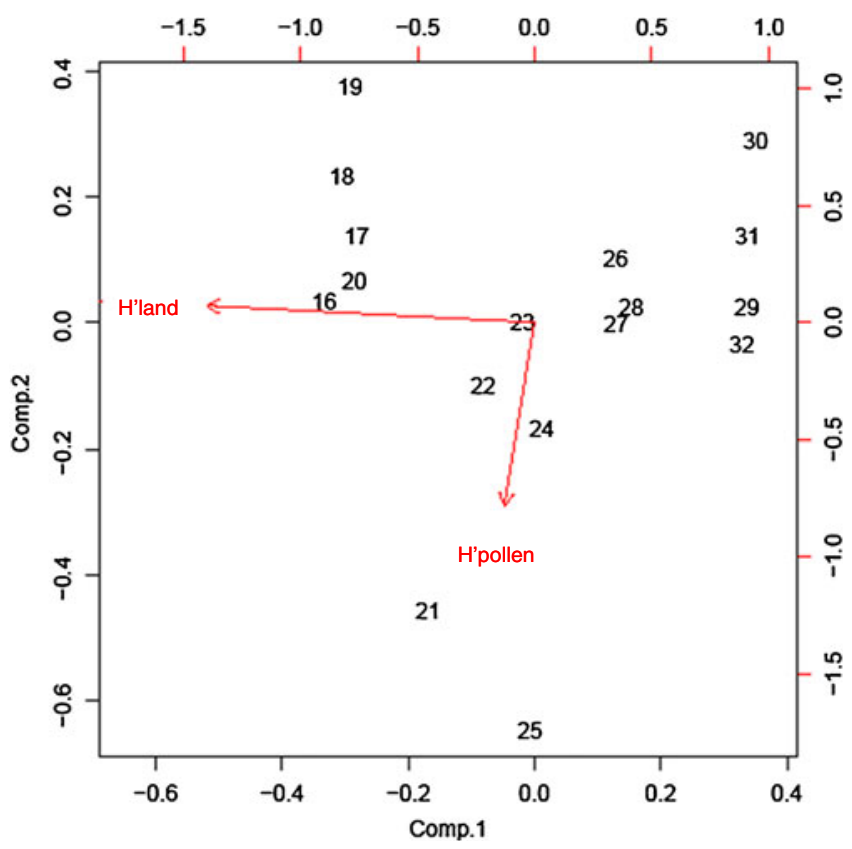


resource assessment than only considering crop areas. The relationship between diversity of pollen and landscape is illustrated by the importance of a mixed landscape especially in spring when the pollen quantities are low. The role of grasslands in this relationship is obvious in spite of a reduced influence during the rest of the year (Figure 5).

The pollen quantity foraged from weeds was as abundant as that collected from crops. Modes of agricultural practices generate different kinds of weeds, which bloom in crops and in borders. It is noticeable that in cereal fields, Veronica was one of the only pollen resources for bees in early spring, when woods (Corylus) had finished blooming and hedgerows (Prunus spinosa in particular) were not yet in bloom. In late spring, when bee colonies reach their peak populations, Papaver, a quality pollen according to Louveaux (1968) and Maurizio (1950), ranked almost as high as maize with up to $36 \mathrm{~g} /$ $\mathrm{d} /$ hive. Obviously, the abundance of this keyrole plant in cereals and set-aside fields is associated with the weeding method and turnover (Cirujeda et al. 2003). Some of these weeds are native to the West of France (e.g., Papaver, Sinapis, etc.), other important ones are not (e.g., Reseda, Ammi, etc.). In mid-August, during the "inter-crop" period, the taxa Daucus/ Ammi, Cichorium, Hypericum, Plantago, Mercurialis, and Reseda represented more than $50 \%$ of the total pollen harvest whereas at the end of summer the group of taxa: Melilotus, Mercurialis, Reseda, Sinapis, Veronica, and Cichorium reached $88 \%$ of the harvest. These results are consistent with authors who underlined the importance of forbs and their role in sustaining bee populations and beekeeping activities (Louveaux 1968; Odoux et al. 2009; Decourtye et al. 2010).

Pollen collection of Helianthus annuus and $B$. napus covered 10 and 6 weeks, respectively, but exceeded $25 \%$ of the weekly collection for only 2 weeks each. In the yearly pollen harvest of our experimental colonies, Z. mays was the major plant foraged by honey bees. It was the dominant $(>50 \%)$ species during 5 weeks despite its restricted cultivation area (4\%). This suggests a high attractiveness of this pollen while sunflower was widely in bloom at this time of year. In addition, according to authors, the exin structure may have an influence on pollen grooming (Vaissiere and Vinson 1994). This abundant collect of maize pollen has already been measured (Odoux et al. 2004) and is often reported by beekeepers. Our data are consistent with observations in a Swiss poly-culture environment where bees shifted to alternative pollen sources such as Zea or Trifolium after collecting Helianthus pollen during a few days (Charriere et al. 2010). Pollen foraging on Zea have to be considered with regard to specific hazards (irrigation and pesticide use) to bees. Yet, despite the large amounts of Zea pollen combined with the sunflower honeyflow, the brood activity falls at this period suggesting that this food supply does not meet protein and lipid needs.

Woods provided a large part of pollen resources to bees in a cereal farming context. Trees and also borders and hedgerows represented around $50 \%$ of the foraged species during spring. This study revealed the major role of woods for bees all year round. In addition, the relationship between the wood area and its contribution to pollen harvest indicated an over-representation of this habitat in the spring collect during rapeseed bloom. The relationship observed in our study shows that grasslands were foraged for pollen when resources of woods and crops were low. The prairie area was more than three times bigger than that of maize and supplied only $10 \%$ of the latter. Grasslands did not clearly affect the pollen collection at any time of the year except in early spring (cluster I) where $23 \%$ of the $196 \mathrm{~g} /$ colony was supplied by this habitat. This can be interpreted by the management of "artificial" grasslands, using Poaceae species as the main crop and incompatible with a high biodiversity (Plantureux et al. 2005). In our study, gardens were essentially rural ones and did not cover a large area (the same as maize). Elaeagnus, Platanus, Berberis, Viburnum, Aesculus, etc., did not have a visible impact on the pollen harvest at any time which is opposite to observations in urban areas where ornamental species allowed bees to feed all year round (Loublier 2010) 


\subsection{Relationship between the physico- chemical composition, landscape and pollen collected}

The resources index and the habitat proportions were not correlated with any physicochemical content of the pollen collected. Our results showed that the intake of the main components, was more related to the quantities foraged than to the rate variations of components. Protein and lipid supplies were mainly correlated with the harvest from crops and woods. The pollen harvest depends for a large part on the availability of flowers and also on the weather conditions enabling bee foraging.

The primary energy source is directly found in nectar by bees, but bees are known to agglomerate nectar to pollen in order to build their loads in case of dry weather (Clark and Lintas 1992; Chauzat and Pierre 2005). Sugar-high pollens came from wood border plants (Cornus, Daucus/Ammi, and Papaver) and crops (Z. mays, Sorghum, and Helianthus).

Pollen is the protein source for the bee, and is important for metabolism and development. According to Maurizio (1950) and Louveaux (1959), spring protein-high pollen diet was consistent with the development period of the colonies, and our loads had a higher value compared with some other authors' observations (Maurizio 1950; Roulston and Cane 2000). Fruit tree pollen (including wild ligneous Rosaceae) has been cited by authors who classed it as "excellent" from the point of view of protein content, but our data also clearly showed the role of a characteristic species of cropped landscape, Papaver in providing protein. During weeks 24-29 the protein deficiency was a consequence of the temporary food shortage and low values of the input diet. Helianthus pollen was the major species in week 27 and has been mentioned as a protein-low taxon, i.e., $15 \%$ by Pernal and Currie (2000) and Tasei and Aupinel (2008). The low protein content of Z. mays (from $14 \%$ to $15 \%$, according to Stace 1996 and Somerville 2001 and confirmed in our analyses of pure Zea pollen) was balanced by the high quantities collected by our bees, which resulted in high summer protein amounts (weeks 28-32). In autumn, there are discrepancies between our data and Louveaux's (1959) observations showing that the protein rate of the gathered pollen did not decrease, and this can be explained by environmental differences.

In our study, the foraged species are actually considered to be protein-rich pollen (Sinapis $27 \%$ and Hedera 28\%, according to Tasei and Aupinel 2008), but the quantities collected were low so the protein amount really decreased.

The lipids brought to the hives are an essential element of bee physiology, especially for larval development and the bee's immunity system (Evans et al. 1991; Feldlaufer et al. 1993; Hornitzky 2003; Alaux et al. 2010). Indication that pollens with higher lipid levels are more attractive to honey bees (Singh et al. 1999) was not verified here in summer. The most important collected quantities were observed in spring, at the same time as protein-rich pollens i.e. during the blooming time of Cornus and Papaver. The species identified in this environment seem to produce very lipid-rich pollens with a mean of $12.6 \%$. Australian bee-collected pollens provide opposite examples with average fat content of $2.5 \%$ (Somerville 2001). Lipid-low inflows in weeks 24-27 could have consequences on the health and development of the next nurses which may affect the lifespan of autumn workers and consequently the wintering mortality of colonies. The main flora supplying such pollens was from edges (Rosaceae) and crop areas (Daucus/Ammi, Helianthus, and Polygonum). The autumn amount of lipids was low in spite of the very high rate of lipids in the pollens harvested, mainly due to low temperatures after mid-October.

Based upon the need for a varied food quality, simplified landscape management generally has negative consequences on the food resources (Day et al. 1990; Geiger et al. 2010). Considering our results, the establishment of flowering set-aside fields should be recommended in summer as a priority in cereal-oilseed crop systems during the summer period, assuming that enough water is available. Therefore, this study shows the interest 
as far as bees are concerned to leave fields without any farming practice for several weeks after the crop harvest, in order that colonies rear their winter workers. Finally, the weeds plants seem to be a very important pollen source, and have to be considered in the environmental ability of a landscape to feed pollinators.

\section{ACKNOWLEDGMENTS}

This research was supported by grants from INRA SPE Department and Franco-Romanian programme "PHC Brancusi" helped by A. Jeannel at INRA MRI Department. The authors would like to thank N. Moreau, T. Souché at Le Magneraud, and R. Spulber in Bucharest for physico-chemical analysis. We also thank H. Lamy, and T. Tamic for palynology analyses, M. Chabirand for land use recording and L. Roucher for pollen sampling, all from Le Magneraud. We wish to thank J. Coates for her critical reading in English.

Biodiversité territoriale et conséquences sur les caractéristiques du pollen récolté par les colonies d'abeilles

Agrosystème / abeille/biodiversité florale / analyse pollinique / analyse chimique

Territoriale Biodiversität und Konsequenzen für die physiko-chemischen Eigenschaften von Pollen, der von Bienenvölkern gesammelt wird.

Agrarökosystem / florale Biodiversität / Pollenanalyse / chemische Analyse / Honigbiene

\section{REFERENCES}

Agreste, MAAPRAT (2011) Répartition du Territoire. 2009-2010 semi-définitive [online]. Available at: http://www.agreste.agriculture.gouv.fr/thematiques/ territoire-environnement. Accessed 05 July 11

Alaux, C., Ducloz, F., Crauser, D., Le Conte, Y. (2010) Diet effects on honeybee immunocompetence. Biol. Lett. 6, 562-565

Benton, T.G., Vickery, J.A., Wilson, J.D. (2003) Farmland biodiversity: is habitat heterogeneity the key? Trends Ecol. Evol. 18, 182-188
Bienkowska, M., Pohorecka, K. (1996) Results of pollen trapping dependent on the size of holes in the insert scraping pollen pellets. Pszczelnicze Zeszyty Naukowe 40, 95-101

Brian, A.D. (1957) Differences in the flowers visited by four species of bumble-bees and their causes. J. Anim. Ecol. 26, 71-98

Campana, B.J., Moeller, F.E. (1977) Honey bees: preference for and nutritive value of pollen from five plant sources. J. Econ. Entomol. 70, 39-41

Charriere, J.D., Imdorf, A., Koenig, C., Gallmann, S., Kuhn, R. (2010) Do sunflowers influence the development of honey bee, Apis mellifera, colonies in areas with diversified crop farming? J. Apic. Res. 49, 227-235

Chauzat, M.P., Pierre, J. (2005) L'importance du pollen pour l'abeille domestique. Bull. Techn. Apic. 32(1), $11-17$

Cirujeda, A., Melander, B., Rasmussen, K., Rasmussen, I. A. (2003) Relationship between speed, soil movement into the cereal row and intra-row weed control efficacy by weed harrowing. Weed Res. 43, 285-296

Clark, C.J.L., Lintas, C. (1992) Chemical composition of pollen from kiwifruit vines. N. Z. J. Crop Hortic. Sci. 20, 337-344

Cox-Foster, D.L., Conlan, S., Holmes, E.C., Palacios, G., Evans, J.D., Moran, N.A., Quan, P.L., Briese, T., Hornig, M., Geiser, D.M., Martinson, V., vanEngelsdorp, D., Kalkstein, A.L., Drysdale, A., Hui, J., Zhai, J.H., Cui, L.W., Hutchison, S.K., Simons, J.F., Egholm, M., Pettis, J.S., Lipkin, W.I. (2007) A metagenomic survey of microbes in honey bee colony collapse disorder. Science 318, 283-287

Day, S., Beyer, R., Mercer, A., Ogden, S. (1990) The nutrient composition of honey bee collected pollen in Otago, New Zealand. J. Apic. Res. 29, 138-146

Decourtye, A., Mader, E., Desneux, N. (2010) Landscape enhancement of floral resources for honey bees in agro-ecosystems. Apidologie 41, 264-277

Elser, E., Ganzmüller, J. (1931) Die chemische Zusammensetzung einiger Blütenstaubarten. Z. Physiol. Chem. 194, 21-32

Evans, D.E., Rothnie, N.E., Palmer, M.V., Burke, D.G., Sang, J.P., Knox, R.B., Williams, E.G., Hilliard, E.P., Salisbury, P.A. (1987) Comparative analysis of fatty acids in pollen and seed of rapeseed. Phytochemistry 26(7), 1895-1897

Evans, D.E., Taylor, P.E., Singh, M.B., Knox, R.B. (1991) Quantitative analysis of lipids and protein from the pollen of Brassica napus L. Plant Sci. 73, 117-126

Feldlaufer, M.F., Knox, D.A., Lusby, W.R., Shimanuki, H. (1993) Antimicrobial activity of fatty-acids against Bacillus larvae, the causative agent of American foulbrood disease. Apidologie 24, 95-99

Folch, J., Lees, M., Sloane-Stanley, G.H. (1957) A simple method for the isolation and purification of total lipids from animal tissue. J. Biol. Chem. 226, 497-509 
Fried, G., Petit, S., Dessaint, F., Reboud, X. (2009) Arable weed decline in Northern France: crop edges as refugia for weed conservation? Biol. Conserv. 142, 238-243

Geiger, F., Bengtsson, J., Berendse, F., Weisser, W.W., Emmerson, M., Morales, M.B., Ceryngier, P., Liira, J., Tscharntke, T., Winqvist, C., Eggers, S., Bommarco, R., Part, T., Bretagnolle, V., Plantegenest, M., Clement, L.W., Dennis, C., Palmer, C., Onate, J.J., Guerrero, I., Hawro, V., Aavik, T., Thies, C., Flohre, A., Hanke, S., Fischer, C., Goedhart, P.W., Inchausti, P. (2010) Persistent negative effects of pesticides on biodiversity and biological control potential on European farmland. Basic Appl. Ecol. 11, 97-105

Genissel, A., Aupinel, P., Bressac, C., Tasei, J.N., Chevrier, C. (2002) Influence of pollen origin on performance of Bombus terrestris micro-colonies. Entomol. Exp. Appl. 104, 329-336

Glinski, Z., Kostro, K. (2007) Colony collapse disorder-a new threatening disease of honey bees. Zycie Weter. 82, 651-653

Haydak, M.H. (1970) Honey bee nutrition. Annu. Rev. Entomol. 15, 143-156

Hornitzky, M. (2003) Fatty acids - an alternative control strategy for honeybee diseases, p. 13. Rural Industries Research and Development Corporation, Kingston

Jauzein, P. (2001) Biodiversité des champs cultivés: l'enrichissement floristique. Dossier de l'environnement de l'INRA 21, 43-64

Kievits, J. (2007) Bee gone: colony collapse disorder. Pestic. News 76, 3-5

Lavie, P., Fresnaye, J. (1963) Étude expérimentale de la trappe à pollen en position supérieure. Ann. Abeille 6, 277-301

Le Conte, Y. (2008) Climate change: impact on bee populations and their illnesses. Revue scientifique et technique-Office international des Epizooties 27, 499510

Loublier, Y. (2010) Utilisation de l'abeille domestique comme bio-indicateur en zone urbaine à St Denis. Le biodiversitaire 4, 75-78

Louveaux, J. (1958) Recherches sur la récolte du pollen par les abeilles. Ann. Abeille 1, 197-222

Louveaux, J. (1959) Recherches sur la récolte du pollen par les abeilles (Apis mellifera L.). Ann. Abeille 2, 99

Louveaux J. (1968) Étude expérimentale de la récolte du pollen. In: Chauvin R. (ed.) Traité de biologie de l'abeille, Masson et Cie, Paris, vol. 3, pp. 174-203.

Louveaux, J., Maurizio, A., Vorwohl, G. (1978) Methods of melissopalynology. Bee World 59, 139-157

Manning, R. (2001) Fatty acids in pollen: a review of their importance for honey bees. Bee World 82, 60-75

Maurizio, A. (1950) The influence of pollen feeding and brood rearing on the length of life and physiological condition of the honey bee. Bee World 31, 9-12
Odoux, J.F., Lamy, H., Aupinel, P. (2004) L'abeille récolte-t-elle du pollen de maïs et de tournesol? La Santé de l'Abeille 201, 187-193

Odoux, J.F., Lamy, H., Loublier, Y., Clement, M.C., Decourtye, A., Aupinel, P. (2009) Palynology contribution in assessment of the beekeeping interest from flowering fallows. Apimondia, Montpellier

Olivereau, F. (1996) Les plantes messicoles des plaines françaises. Le Courrier de l'environnement 28, 5-18

Pernal, S.F., Currie, R.W. (2000) Pollen quality of fresh and 1-year-old single pollen diets for worker honey bees (Apis mellifera L.). Apidologie 31, 387-409

Plantureux, S., Peeters, A., McCracken, D. (2005) Biodiversity in intensive grasslands: effect of management, improvement and challenges. Agron. Res. 3, 153-164

Roulston, T.H., Cane, J.H. (2000) Pollen nutritional content and digestibility for animals. Plant Syst. Evol. 222, 187-209

Shannon, C.E., Weaver, W. (1949) The mathematical theory of communication. University of Illinois Press, Urbana. $117 \mathrm{p}$

Singh, S., Saini, K., Jain, K.L. (1999) Quantitative comparison of lipids in some pollens and their phagostimulatory effects in honey bees. J. Apic. Res. 38, 87-92

Somerville, D.C. (2001) Nutritional value bee collected pollens, pp. 1-176. NSW Agriculture, Goulburn

Stace, P. (1996) Protein content and amino acid profiles of honeybee-collected pollens. Bee N' Trees Consultants, Lismore, NSW Australia, p 2480.

Standifer, L.N., McCaughey, W.F., Dixon, S.E., Gilliam, M., Loper, G.M. (1980) Biochemistry and microbiology of pollen collected by honey bees (Apis mellifera L.) from almond, Prunus dulcis. 2. Protein, amino acids, and enzymes. Apidologie 11, 163-171

Steffan-Dewenter, I., Kuhn, A. (2003) Honeybee foraging in differentially structured landscapes. Proc. R. Soc. Lond. Series B-Biol. Sci. 270, 569-575

Tasei, J.N., Aupinel, P. (2008) Nutritive value of 15 single pollens and pollen mixes tested on larvae produced by bumblebee workers (Bombus terrestris, Hymenoptera: Apidae). Apidologie 39, 397409

Vaissiere, B.E., Vinson, S.B. (1994) Pollen morphology and its effect on pollen collection by honey-bees, Apis mellifera (Hymenoptera, Apidae), with special reference to upland cotton, Gossypium hirsutum L. (Malvaceae). Grana 33, 128-138

vanEngelsdorp, D., Evans, J.D., Donovall, L., Mullin, C., Frazier, M., Frazier, J., Tarpy, D.R., Hayes, J., Pettis, J.S. (2009) "Entombed pollen": a new condition in honey bee colonies associated with increased risk of colony mortality. J. Invertebr. Pathol. 101, 147-149

Winston, M.L. (1994) La biologie de l'abeille. Nauwelaerts, Beauvechain, Belgium 